\title{
FÖRINTELSEN I LITTERATUREN
}

\author{
Karl-Johan Illman
}

Åbo

\section{Inledning}

Grunden för den judiska katastroflitteraturen lades i Bibeln. Till den bör vi räkna framför allt Klagovisorna och en rad psalmer i Psaltaren. Då klagade man över första templets fall och andra nationella katastrofer. Dessa kom tillsammans med de s.k. kinôt-dikterna att reciteras i den judiska liturgin under Tish'a b'Av till åminnelse av de båda templens förstörelse. ${ }^{1}$ Senare har andra katastrofer $\mathrm{i}$ den judiska historien såsom fördrivningen från Spanien 1492 och framför allt förintelsen under andra världskriget krävt sin egen litteratur. Förintelselägrens uppkomst och verksamhet skildras som bekant inte bara i historiska verk och memoarer utan också i dikt och roman, ofta med starka självbiografiska inslag. Dagböckerna hör till de viktigaste dokumenten vi har om vad som skedde där. Redan en blick på den enorma litteraturen om förintelsen säger oss, att uppdelningen i skönlitteratur och historia inte räcker till. T.ex. psykologin och psykiatrin är sådana fack som under årens lopp bidragit med många viktiga undersökningar. Även teologin, både judisk och kristen, har allt mera börjat befatta sig med ämnet. När jag här försöker ge en begränsad orientering $\mathrm{i}$ den litteratur som behandlar "holocaust", gör jag ett urval närmast ur två genrer: dels dokumentariska verk, främst självbiografier, och dels fiktiva, vad vi kallar skönlitterära, gestaltningar av temat.
Av de verk som jag använt vill jag nämna speciellt Sidra Dekoven Ezrahis By Words Alone (1980), som inträngande analyserar förintelsetemat i den moderna litteraturen.

\section{Om terminologin}

På ett internationellt plan dominerar ordet "holocaust" som beteckning för förintelsen. Det härleds från grekiskans holokautôma, som ursprungligen betecknade det "helt uppbrända", ett "brännoffer". Under 1600- och 1700-talen började termen i engelskt språkbruk användas för att beteckna en fullständig förintelse av ett objekt, en plats eller en grupp, oftast genom eld, men också genom naturkatastrofer. ${ }^{2}$ I vår tid används termen för att beteckna förintelsen av de sex miljonerna judar under andra världskriget. Den infördes av ingen mindre än Elie Wiesel. Han säger sig ha sökt en term med ett "ontologiskt, mystiskt" innehåll och untgick då från den hebreiska bibelns term 'olah ${ }^{3}$ eftersom den har med eld att göra och betecknar ett fullständigt offer. Wiesel har senare dock beklagat, att han förde fram denna term, därför att den - samtidigt som den blev mycket använd - också blev utnött och trivial. $^{4}$ Man kan ifrågasätta termens lämplighet också på innehållş̧iga grunder. "brännoffer" - till vem då, för vad? ${ }^{5}$ Svaret att det är ett offer "till Israels Gud" är för Wiesel liksom för de flesta andra holocaustförfattare helt uteslutet, men det

1 Hela den judiska katastroflitteraturen behandlas av David G. Roskies i monografin Against the Apocalypse (1984). Om den bibliska och klassiska klagolitteraturen, se Roskies 1984, 15-52. Roskies publicerade fem år senare ett stort antal viktiga texter ur denna litteratur i sin antologi The Literature of Destruction (1989).

2 Se Lang 1990, xx-xxi.

3 Denna term återges i den grekiska översätningen av hebreiska bibeln, Septuaginta, vanligen med holocautôma, să Lex. i Ex. 10:25; Hes 10:6.

4 Wiesel, Lebensstationen (1987), 64; jfr Illman 1989, 477.

5 Lang 1990, xxi-xxii, framhåller att termen använd om nazistemas folkmord inte anger någon intention varken hos de "offrade" 
finns exempel på en tidig judisk holocaustteolog som faktiskt vill se saken så. ${ }^{6}$ Själva erfarenheten av förintelsen kan för en som vuxit upp i en religiös tradition direkt kräva en religiös term. Den ursprungliga offertermen "holocaust" kunde då kanske i överförd mening bibehållas för att säga, att det var ett offer för en ideologi, för främlingshatet eller för likgiltigheten inför mänskligt lidande och undfallenheten inför våld och brutalitet.

På senare tid har många börjat föredra neutralare uttryck som de hebreiska shoah, "olycka", "oväder", eller churban, "förstörelse" (jfr Job 30:3) och "katastrof". ${ }^{7}$ Det jiddiska uttrycket der driter khurbn, "den tredje förstörelsen", syftar på förintelsen, medan de två tidigare avser första och andra templens förstörelser. Wiesel har för egen del sagt, att alla termer är blasfemiska, men att shoah är en sämre term än "holocaust", därför att den i regel betecknar naturkatastrofer, medan "holocaust" indicerar det mystiskt-religiösa i händelsen. Han tycks plädera för churban, som också är den äldsta termen och var gängse bland judarna i Palestina, innan David Ben Gurion och staten Israel gick in för shoah. ${ }^{8} \AA$ andra sidan har kanske termen "holocaust" visat sig användbarast just därför att den blivit så vanlig.

Om vi änd̊̊ väljer det svenska ordet "förintelsen", är frågan den om vi blir förstådda utanför en kulturell, kristen eller judisk kontext. $\AA$ andra sidan är denna term uttrycksfull, när man använder den absolut $\alpha$ ch i bestämd form. I denna uppsats kommer jag därför att huvudsakligen använda "förintelsen".

\section{Dagböcker och memoarer}

Det finns en ständigt pågående diskussion, som jag här inte kan gå in på, om huruvida förintelsen är unik eller jämförbar med andra folkmord som historien känner. Hur man än ställer sig till den frågan, är händelsen i ett avseende olik alla andra kända folkmord: den har gett upphov till en omfattande litteratur skriven både av offren och de överlevande. I oktober 1939 startade historikern Emanuel Ringelblum en grupp som kallade sig Oyneg Shabbes, "Sabbatsglädjen", som under mycket svåra förhållanden satte upp ett underjordiskt arkiv av anteckningar, dagböcker m.m. som begravdes i mjölkkannor, fotogenburkar m.m. Efter Warszawa-gettots utplånande tog sig Ringelblum själv över till den "ariska" sidan av staden och fortsatte sin verksamhet, men år 1944 arresterades han med sin familj av Gestapo och mördades. Arkivmaterialet ăterfanns i betydande utsträckning och är utgivet i två band. Det innehåller bl.a. en beskrivning av Oyneg Shabbes. ${ }^{10}$ En annan medlem av gruppen, Chaim A. Kaplan, skrev en dagbok som han lät smuggla ut i delar som sedermera sammanställts och utgivits även i svensk översättning. ${ }^{11}$ Kaplan torde ha omkommit i Treblinka, dit en stor del av Warszawa-gettots judar hösten 1942 deporterades. En senare utgiven dagbok från Warszawagettot fördes av Abraham Lewin. Den är också endast delvis bevarad. Liksom Ringelblum och Kaplan överlevde inte heller Lewin förintelsen utan torde ha mist livet $\mathrm{i}$ januari 1943. ${ }^{12}$ Det kanske senaste tillskottet är Abraham Torys dagbok från gettot $\mathrm{i}$ Kovno, Litauen, från åren 19411943. Författaren skrev och dikterade för sin väninna, ombesörjde själv nedgrävningen av dagböckerna, men kunde efter befrielsen inte finna hela manuskriptet. ${ }^{13}$ I gettona förekom sålunda en febril litterär aktivitet. Man skrev

eller dem som "offrar" och att inget gott kommer från detta "offer". Inte heller hade den något gemensamt med naturkatastrofer. Han vill därför undvika den och talar i stället om nazistemas folkmord.

6 Ignaz Maybaum i The Face of God after Auschwitz (1965), 67. Om den s.k. holocaust-teologin i övrigt, jämför Illman 1982 och Rubenstein-Roth 1987, 290-336.

7 Roskies 1984, 41-43, jfr Ezrahi 1980, 2.221.

8 Se en intervju från 1987 publicerad i Wiesel / de Saint-Cheron 1990, 38-40.58f.

9 Ksovim fun geto 1 (1939-42), 2 (1942-1943), Warsaw 1961, 1963 (rev. uppl. Tel Aviv 1985). En engelskspråkig oversättning utkom redan 1958: Notes from the Warsaw Ghetto.

10 Roskies 1988, 386-398.

11 Kaplan - Katsh 1965. Dagboken skrevs på hebreiska och är även översatt till engelska: Scroll of Agony.

12 Den sträcker sig från 26 mars 1942 till 15 jan 1943, men skall enligt Ringelblum ha förts i ett och halvt år. Se Polonskys inledning till dagboken, Lewin 1989. 53.

13 Tory 1990. Dagboken användes redan före sin publicering vid flera tillfällen som bevismaterial mot naziförbrytare. Se Martin Gilberts introduktion. 
förutom dokumentärt material även dikter, romaner etc av vilka bara en liten del har bevarats till eftervärlden. $^{14}$

Förintelselitteraturen är idag trots förlusterna ändå hart năr oöverskådlig. Av den dokumentära litteraturen har Yad Vashem-arkivet i Jerusalem de största samlingarna.

\section{Vad är verkligt?}

I studiet av förintelselitteraturen kan det uppstå problem som gäller skillnaden mellan "fakta" och "fiktion". Kan man göra en skarp gräns mellan historiska försök att berätta om vad som "faktiskt hände" och försök till fiktiv litterär gestaltning? Många hyser kanke en misstanke, att det senare på något sätt undergräver sanningen. ${ }^{15}$ När det gäller att bedöma förintelselitteraturen, är det helt klart, att ingen omedelbar bild av dess verklighet finns att tillgå. En dagbok som förs dag efter dag i ett läger eller ett getto återspeglar vad författaren visste och upplevde just när det hände. Hans perspektiv är en sanning, givetvis begränsad till vad han kände till och färgad av hans personliga upplevelse. Om vi tar en memoarbok skriven kort efter det som skedde, är den ett slags återskapande av verkligheten kompletterad med sådant som författaren fått veta efter befrielsen. Men kan man efteråt klart beskriva vad man då under helt andra förhållanden upplevde? Kanske, men här som i andra sammanhang ger beskrivningen en modifierad bild, som är färgad av många associationer och erfarenheter från senare tid.

Trots tolkningsmässigheten eller kanske tack vare den, kan det skönlitterära verket faktiskt föra oss närmare själva händelsen, när det låter smärtan, sorgen och förlusten gestalta erfarenheten. Skillnaden mellan dessa båda sätt att nalkas samma sak står kvar, men den är inte lätt att sätta på en formel.

Lawrence Langer tar ett exempel från Wiesels Natten: Eliezer (= Wiesel) säger: "Jag förnekade inte Guds existens, men jag betvivlade hans absoluta rättvisa". Tanken kan säkert âterge en genuin uppfattning hos Wiesel själv. Samtidigt kommer formuleringen nära ett uttalande av Ivan Karamasov hos Dostojevskij: "Det är inte det att jag inte kan acceptera Gud, förstår du, det är den värld som han skapat som jag inte kan acceptera." Om man betänker att huvudpersonen i Wiesels tredje bok, Dagen, blir påkörd av en bil då han är på väg till en biograf för att se Bröderna Karamasov, kan man tänka sig att det förekommit en påverkan i efterhand. ${ }^{16}$ Men likheten $i$ tolkningar av en förödande händelse kan också vara slumpmässig.

När det gäller att ta ställning till vad som kunde ge den mest autentiska bilden av Auschwitz, pekar Langer på muntliga vittnesbörd av vittnen till förintelsen. Han anser att sådana kan betraktas som "refreshing texts", ifall de intervjuade kan bortse från intervjusituationen och intervjuarens försök att få dem att dra slutsatser m.m. ${ }^{17}$

Berel Lang framhåller för sin del att den fiktiva framställningen av förintelsen löper större risker att förvanska förintelsen än den dokumentära, men att man bör ställa samma moraliska krav på vardera. ${ }^{18}$ Man kan dock fråga sig om inte den rent dokumentära framställningen av förintelsen är den mest distanserande. Siffror är siffror och inte alltid som sådana ägnade att tjäna förståelsen av vad som skedde. Här vill jag anföra Leo Eitingers reflexioner över antalet dräpta i Auschwitz: "Talet 4 millioner drepte i en leir, sier det noe? Fire millioner, det er den totale norske befolkning og vel så det. Det er hvert barn, hver voksen, hver olding, hver kvinne og hver mann på hvert eneste sted i Norges land... Jeg kunne fortsette i det uendelige og jeg vet ikke om vi vil være $\mathrm{i}$ stand til å forestille oss disse 4 miljoner drepte, dvs. hele Norge, fullstendig mennesketom - uten en levende sjel. Hver eneste by, hver eneste bygd, hvert eneste fiskevær avfolket - drept - tillintetgjort."19

Det sagda kan också illustreras med skillnaden mellan två av vår tids mest kända filmer om förintelsen. Den ena är baserad på Gerald Greens roman Holocaust från 1978. Här har vi den

14 Roskies 1984, 196-224. Antologin, Roskies 1988, 381-464, imeh \&ller utdrag ur Emanuel Ringelblums arkiv, Shimon Huberband, Peretz Opoczynski, Leyb Goldin, Chaim Kaplan, Yehoshue Perle, Rachel Auerbach och en anonym beksrivning av hur Warszawa-gettot brann. Det följande kapitlet (s.465-501) upptar tio getto-poeter.

15 Ezrahi 1980, 8. Jfr Raoul Hilbergs artikel "I Was Not There" i Lang 1988, 17-25 och Lang 1990, $125-140$.

16 L. Langer, Interpreting Survivor-Testimony, Lang 1988, 28.

17 Langer 1982, 39; jfr den ingående analysen av sådana "holocaust testmonies" i Langer 1991.

18 Lang 1990, 117-125.140-150.

19 Eitinger 1985, 95. 
fiktiva berättelsen om två familjer, Dorf och Weiss, och deras öden under förintelsen. De fiktiva partierna omväxlas med dokumentärt arkivmaterial från krigstiden. Men det fiktiva överväger och inramar handlingen. Annorlunda förhåller det sig med Claude Lanzmanns film från 1985, Shoah, som helt baserar sig på intervjuer och vittnesmål av personer som var med bödlar och offer. Den är inte fiktiv, men inte heller dokumentär i den meningen, att hela materialet skulle härstamma från den tiden, utan det är frågan om en rekonstruktion. Därtill kommer den enorma skillnaden i själva presentationen: den romantiserande storyn i Holocaust i motsats till den krassa domstolsliknande dialogen $i$ Shoah. Vilken ger en trognare bild av förintelsen? De som sett vardera filmen eller läst bägge böckerna skulle sannolikt rösta för Lanzmanns version. De skulle säga att Greens Holocaust ger varken en konstnärligt eller dokumentärt tillfredsställande bild, medan Lanzmann nått långt speciellt på det dokumentära och samtidigt presterat betydande konst. $^{20}$

Begreppet "det koncentrerade universum" formulerades på franska (l'univers concentrationnaire) av David Rousset ${ }^{21}$ för att beteckna inte bara koncentrationslägermiljön utan också förhållandena för judarna i Europa under andra världskriget. Karakteristiskt för dessa var att oberoende av var judarna befann sig, var de dömda till förintelse. I lägren, gettona och under transporterna behandlades de $\mathrm{i}$ allmänhet brutalare än andra făngar. Till skillnad från andra grupper som $i$ viss utsträckning hade möjlighet att välja - t.ex. om de var motståndsmän eller inte - hade judarna, liksom zigenama, ingen möjlighet att välja - de var judar genom biologisk härstamning.

Trots de nämnda skillnadema kan man säga att alla dessa andra individer och grupper som förföljdes och deporterades delade ett "lingvistiskt universum" med judarna. Ett starkt inslag i detta var nazisternas speciella och perverterade tyska (Nazi-Deutsch), som kom att påverka inte bara det samtida tyska språket utan också de andra språk som lägerfângarna talade. Främst gäller detta jiddish, som alltid har mottagit inflytelser från värdbefolkningens och fơrtryckarnas språk. Men förintelsen accelererade framför allt judamas benägenhet att uppta nya och byta språk. De som överlevde förintelsen kom ju att leva som flyktingar i många olika länder och för dessa det blev det snarare undantag än regel, att man i tal och skrift fortsatte att uttrycka sig på samma språk som före förintelsen. Engelskan utövade en stor lockelse, därför att den var befriarnas språk som man kunnat lyssna till redan under kriget i BBC's nyhetssändningar. Många holocaustförfattare kom sålunda att börja skriva på engelska, franska etc. Men som flyktingar ("displaced persons") hade de inga kulturella kontakter till de länder där de här språken talades. Även när de övertar det nya språket, kommer de därför att använda sig av en speciell vokabulär för sina lägererfarenheter. Holocaustförfattarna är avskurna från sin egen ursprungliga språkliga och kulturella miljö och är inte heller inplanterade $i$ någon ny sådan. Utby tbarheten när det gäller språket är i själva verket ett karakteristikum för förintelsen, lägervistelsen och litteraturen. Häri skiljer sig förintelselitteraturen från all nationell litteratur och från "litteraturen" på något bestämt språk. Den är ett slags transnationell litteratur som härstammar från en gemensam effarenhet och använder en gemensam vokabulär, som är både personlig $\propto c h$ internationell, men aldrig nationell. ${ }^{22}$

\section{Litteratur i och om lägren}

Det finns som ovan nämnts en judisk klagolitteratur, som uppkommit ur behovet att möta de ständigt nya katastrofer som drabbat det judiska folket som kollektiv, alltifrån biblisk tid till våra dagar. I detta continuum infogas också förintelsen som ett kapitel i en lång martyriologi. Det är kanske inte så mycket samma svar som samma frågor som på detta sätt förmedlas av traditionen. Folket har varit hotat förr och förintelsen kan ses som ännu ett hot mot dess överlevnad som folk och de värden det företräder. För individen blir lägererfarenhetema däremot en existentiell kris,

20 En presentation av och reaktionema p\& filmen "Holocaust" levererar Judith E. Doneson i sin bok The Holocaust in American Film (1987), 144-196. Hon anser att den trots sina begränsningar änd̊̊ var viktig. T.ex. sågs den av halva det amerikanska folket och den var för många det första de såg om förintelsen. Den skapade också en öppenhet för senare filmer som Lanzmanns "Shoah".

21 Rousset 1947. Jfr Ezrahi 1980, 10.

22 Ezrahi 1980, 11-13. Hur lägerverkligheten påverkade den språkliga sympoliken kan se tex. därav att askan från ugnama eller skorstenama blir "svart mjölk" ("schwarze Milch") i den bekanta dikten "Todesfuge" av Paul Celan eller "svävande moln" i en annan. 
som skapar symboliska svar vilka är helt annorlunda ån kollektivets svar. Här är perspektivet extremt fokuserat på individen, hans förmåga att överleva och finna en mening. Sidra D. Ezrahi räknar med tre stadier inom denna litteratur, som var och en kan ges dels en kollektiv dels en individuell form, nämligen

1 - dokumentär litteratur, som kan ses som ett mellanstadium mellan vittnesbörd och imaginativ konst; här bibehålls "den historiska processen" som något objektivt givet;

2 - "koncentrationell realism", där individen står i centrum, men där "lägerfakta" ännu har ett starkt grepp om utformningen och

3 - "överlevnadslitteratur", där fakta-dominansen för första gången bryts och utrymme ges ât fantasin - som en väg ut, men också en väg in $i$ det koncentrerade universum som skildras. Här tjänar det judiska folkets kollektiva historia snarare än den individuella biografin som en länk mellan det förgångna $\propto$ ch framtiden. Den mest radikala formen av denna littertur är myten, som ger en tolkningsram i vilken författaren är helt befriad från fakticiteten. ${ }^{23}$

Man kan också ge en annan indelning, beroende på var litteraturen skrivits. Det finns givetvis flera skillnader mellan sådan litteratur som [a] tillkom i gettona eller i lägren och sådan som [b] skrivits efteråt. Jag nämnde redan skillnader i faktabasen. Härtill kommer att den förra inte hade möjligheten till det avstånd $\mathrm{i}$ tid och rum, som ofta är nödvändig för att konstnärlig utformning skall kunna uppnås. Men den litteratur som skrevs i lägren hade funktionen att tjäna motståndet mot förintelsen. En tredje kategori är sådan [c] redan existerande litteratur av olika slag som memorerardes eller fanns att tillgå i lägren och som kunde fylla samma funktion som den första kategorin. ${ }^{24}$ Inte bara $\mathrm{i}$ gettona utan också $\mathrm{i}$ lägren kunde vissa intemer lägga sig till med böcker, $i$ en del fall i form av skräppapper. På detta sätt kunde Eugen Kogon läsa bl.a. Platons dialoger. ${ }^{25}$ Primo Levi berättar om hur han, i en situation då internerna berövats allt, t.o.m. sina namn, började recitera ur Dantes Divina Comoedia för en ung pojke därför att "i morgon kan någon av oss vara död" (se nedan). Här har vi exempel på hur litteratur av olika slag kunde bidra till att stärka motståndskraften i lägren, hur det kunde bli ytterst angeläget att komma ihåg en bestämd rad eller strof av Dante, eftersom den kanske innehåller "förklaringen till vårt öde, till att vi idag befinner oss här .....

Redan långt före deportationema till lägren hade judama i Tyskland börjat känna sig hotade. De fruktade att de eventuellt måste emigrera och lämna efter sig sitt kulturella arv. Detta tog sig uttryck i en stark aktivitet inom judisk litteratur och teater. Elie Wiesel har tagit upp Kafkas yttrande "att skriva är att be" och hävdat att vardera är former för en likartad kreativitet. ${ }^{27} \mathrm{De}$ som inte emigrerade $\mathrm{i}$ tid utan hamnade $\mathrm{i}$ getton och läger grep till litteraturen som protest och flykt. Hemliga manuskript tillkom och i brist på papper skrev man på brädor som flyttades från läger till läger. Teaterpjäser uppfördes. Av den i lägren tillkomna litteraturen har speciellt sådana dikter som skrevs av barn i Theresienstadt väckt stor uppmärksamhet. En del av dem uppvisar en förbluffande mognad och artistisk färdighet som förebådar den förintelsepoesi som skrevs efter${ }_{\text {att. }}{ }^{28}$ I Theresienstadt kunde en judisk orkester uppföra Verdis Requiem, såsom den tjeckisk-judiske författaren Josef Bor berättar i sin Theresienstädter Requiem (1964). Detta att lägerfångarna kunde sätta värde på det klassiska europeiska kulturarvet står i egendomlig kontrast till ett annat faktum - att förintelsen planerades och genomfördes i Tyskland - som före förintelsen kanske var den främsta bäraren av detta kulturarv.

De som skrivit i lägren, men själva inte överlevde, hade $i$ bästa fall lyckats gräva ned sina alster eller smuggla ut dem. Ännu flera år efter det att lägren upplösts, grävde man efter och fann manuskript. Dessa fynd publicerades småningom. Snart började också memoarer och dagböcker av överlevande utkomma. Motiven till publiceringen var flera: behovet att avlägga vittnesbörd, kanske också att hämnas, behovet att ihågkomma de döda, låta dem bli hela och levande i minnet, känslan av att ha ett varnande

Ezrahi 1980, 14.

E. Ringelblum berättar, ant sådana klassiker som Tolstoys Krig och fred ånjöt stor popularitet i Warszawa-ghettot. Se Ezrahi 1980, 17.

Ezrahi 1980, 17-18.

Levi 1988, 129-131; jfr Ezrahi 1980, 18-19.

Paroles d'étranger. Paris 1982, 166. Jfr E.S. Fine 1986, $79-89$.

Se Ezrahi 1980, 16-17. Theresienstadt var dock unikt, eftersom det tjänstgjorde som förevisnings- och genomgångsläger. 
budskap till eftervärlden. Eller så var skrivandet ett led i det egna sorgearbetet, att hitta en mening och få fotfäste $i$ tillvaron. Dessa memoarer är vittnesbörd om det otroliga i vad människor kan uthärda. Samtidigt visar verken, att inte ens den nazistiska "lösningen" var perfekt: de kunde ju faktiskt inte verkställa alla de dödsdomar som de summariskt avkunnat i Wannsee i januari 1942, då man beslöt genomföra "die Endlösung der jüdischen Frage". ${ }^{29}$

Denna dokumentariska litteratur fick inte någon större spridning. Dess framställningssätt var kanske för detaljrikt $\propto$ ch för perspektivlöst för utomstående. Och de som själva varit med kunde ännu inte förmå sig att läsa om händelserna. Det skulle följa ett drygt årtionde, under vilket ganska litet skrevs. Men denna litteratur skulle få en stor betydelse för nya kreativa författare som började publicera på 50- och 60-talen. De började ofta med en memoarbok som sedan utlöste en serie skönlitterära verk. Till den här kategorin hör Primo Levi och Elie Wiesel. ${ }^{30} \mathrm{Jag}$ skall här som exempel kort presentera Primo Levis första memoarbok och Wiesels tredje roman.

\section{Exempel 1: Primo Levi: Är detta en männi- ska?}

Primo Levi (1919-1987) föddes i Turin i en kulturellt medveten judisk familj som tillhörde medelklassen. Den judiska bosättningen i Italien har de äldsta anorna i Europa och den var bärare av betydande religiösa och litterära traditioner. Men vid tiden för Primo Levis uppväxt var den redan i hög grad assimilerad, företrädesvis med det intellektuella skiktet. Sådana familjer höll stundom fast vid banden till judendomen, t.ex. så att sönerna genomgick bar mitsva, så också Primo. Ceremonin betydde dock sällan någon stark religiös identifikation. Vid den här tiden föreföll Italien också vara tämligen fritt från antisemitism. Men detta skulle snart ändra sig: mot slutet av 30-talet började Mussolini efterapa Hitlers brutala antisemitism. Primo Levi hade börjat studera kemi, men fann till sin och sin familjs häpnad att vissa professorer börjat diskriminera judiska studenter. Levi lyckades dock finna en handledare och kunde år 1941 disputera. Han kunde däremot p.g.a. raslagama från 1938 inte få anställning som kemist utan fick nöja sig med ströjobb vid ett fernissalager och en nickelgruva. $^{31}$

Primo Levis memorabok utkom första gången i italienskt original med titeln Se questo è uno uomo redan år 1947 och det framgår att den hade skrivits under tiden december 1945 januari 1947. Det betyder att Levis memoarbok skrivits under det nästan omedelbara intrycket av lägertiden. Tiden mellan befrielsen $\mathrm{i}$ januari 1945 och hemkomsten till Turin i oktober samma år tillbragte Levi p.g.a. av "byråkratisk förvirring" med en "bisarr resa" genom Polen och Sovjet, innan han kunde återvända hem. ${ }^{32}$

Upplagan omfattade bara 2500 exemplar av vilka 600 fanns kvar, när förlaget upphörde. Boken glömdes enligt Levi "också därför att folk vid den tiden, den svåra efterkrigstiden, inte gärna i minnet ville återvända till den nyligen överståndna sorgliga åren". Men, när den kom ut i nytryck år 1958, blev den mycket uppmärksammad [s 201].

År 1976 skrev Primo Levi en efterskrift till en skolutgåva av boken för att besvara frågor som ständigt återkommit från dem som läst boken. Den kommenterar på åtskilliga punkter memoartexten.

$\ddot{A} r$ detta en människa? inleds med en dikt som bär bokens titel och i slutet anspelar på shema' jisra'el, 5 Mos 6:6-7:

Ni som lever trygga

I era ombonade hem,

Ni som vid hemkomsten på kvällen

Finner varm mat och vänliga ansikten:

Tänk efter om detta är en man,

Som arbetar i leran

Som inte vet vad frid är

Som kämpar på ett halvt bröd

Som dör på grund av ett ja eller ett nej.

Tänk efter om detta är en kvinna,

Utan hår och utan namn

Utan ork mer att minnas

Med tomma ögon och kallt sköte

Som en groda om vintern.

Begrunda att detta har hänt.

Jag anbefaller er dessa ord.

Prägla in dem i ert hjärta

29 Ezrahi 1980, 21, med hänvisning till Piotr Rawics.

30 Ezrahi 1980, 22-23.

31 Irving Howe 1985, 4-5.

32 Howe 1985, 8. 
När ni är hemma, när ni ăr på väg,

När ni lägger er, när ni stiger upp,

Upprepa dem för era barn.

Eller ert hem må förstöras,

Sjukdom hämma er,

Och era söner och döttrar vända sitt ansikte ifrån er.

Den avslutande hotelsen anknyter till början. Det som man bör tänka på och inprägla är situationen i lägren och frågan om lägermänniskan är en människa. Man kan säga att dikten i ett nötskal fångar bokens ärenden: förhållandena i lägren och de senare generationers ansvar inför det som hände.

Levis memoarbok är i fortsättningen kronologiskt uppbyggd. Han hade anslutit sig till en motståndsgrupp (Giustizia e Libertà) som organiserades mot det fascistiska styret i Italien. Genom att en medlem av gruppen den 13 december 1943 förrådde dem kunde milisen tillfångata de otränade partisanerna. Under de följande förhören uppgav Levi att han var "italiensk medborgare av judisk ras" [s 10], vilket ledde till att han sändes till ett fångläger som redan då hade 150 italienska judar, men snart över 600. Efter en kort tid anlände tyska nazister till lägret och den 21 februari 1944 meddelades att judama skulle "resa" följande dag. Levi liksom de flesta andra judarna hade av polska och kroatiska flyktingar fătt klart för sig vad det innebar att "resa iväg" [s 11]. Han beskriver därefter deras förberedelser som innehåller starka inslag av sorgeriter: "Var och en tog avsked av livet på sitt sätt ...". Härefter följer en beskrivning av transporten till Auschwitz och mottagandet där som mycket liknar dem vi kan läsa t.ex. hos Wiesel eller Herman Kahan. En snabbselektion vid ankomsten resulterade i att 96 män (inklusive Primo Levi) och 29 kvinnor hamnade i respektive Buna-Monowitzlägret och Birkenau, medan av de övriga drygt 500 inte en enda var $i$ livet två dagar senare. De fördes direkt till gaskamrama.

Levi togs ut till arbete i den av IG Farbenindustrie inrättade Buna-fabriken, som skulle framställa syntetiskt gummi, men aldrig kom så långt. Fabriken och arbetslägret fanns i Monowitz, några kilometer från Auschwitz och Birkenau. Leo Eitinger och Elie Wiesel var vid samma tid intemerade $i$ detta läger som då hade ca 10.000 fångar. Levi är en mästare $i$ att beskriva tillståndet för en Häftling som han själv:
Man måste nu föreställa sig en människa som förutom sina kära berövas sitt hem, sina vanor, sina kläder, kort sagt allt, bokstavligen allt hon äger och har: den människan blir tom, reducerad till att känna lidande $\propto$ ch behov, glömsk av sin värdighet och urskillningsförmåga, ty den som har förlorat allt förlorar lätt sig själv; hon blir alltså sådan att man utan någon som helst känsla av mänsklig frändskap lättvindigt kan bestämma över hennes liv och död, i bästa fall helt enkelt på grundval av en bedömning av hennes nyttighet. Då förstår man den dubbla innebörden av ordet "Förintelseläger" ... [s 25]

Primo Levi oppnonerar sig mot en del rutiner såsom tvättningen och anser att man, om man t.ex. har tio minuter kvar att leva, kan använda dem till att vila, meditera, titta på himlen. Men en äldre intern, Steinlauf, säger emot honom ungefär så här: "just därför att lägret är en stor apparat som ska förvandla oss till djur får vi inte bli djur" [s 41]. Levi lärde sig snart konsten att överleva, börjande med vistelsen i sjukstugan, Ka-Be (Krankenbau). Där gällde det att inte bli sämre, för då bar det iväg till gaskammaren. Det gällde att inte heller bli för fort frisk, för då hann man inte återhämta kraftema. Han făr här tid och krafter att tänka på annat än hunger och arbete, men samtidigt också bli medveten om hur prekärt läget är [s 58].

Levi beskriver olika faser och inslag i sitt lägerliv: arbetet, sjukhuset, nätterna, olika slag av hot, men också glimtar av medmänsklighet hos arbetsledare, vänskap och kamratskap som uppstår i lägret. Handeln med brödransoner, skjortor och annan nödtorft är mycket utvecklad. Det finns en lägerekonomi, där prislagama följer helt interna kombinationer av utbud och efterfrågan. Ett ställe i lägret kallas Börsen. Lägret är ett stort biologiskt och sociologiskt laboratorium, där det enligt Levi finns "två särskilt tydligt âtskilda kategorier av människor, räddade och förtappade. Andra motsatspar (goda och onda, kloka och dåraktiga, fega och modiga, olycksaliga och lyckosamma) är mycket mindre framträdande ..." [s 98]. Det gällde om ville försöka överleva att se till att man hörde till den första kategorin.

Att duka under är det lättaste: det räcker att utföra alla de befallningar man får, att inte äta mera än sin matranson och att iakttaga arbets- och lägerdisciplinen. Erfarenheten 
har visat att man endast undantagsvis kan klara sig mer än i tre månader på det viset. Alla muselmaner som hamnar i gasen har samma historia bakom sig, eller rättare sagt de har ingen historia alls ... Sedan de anlänt till lägret har de beroende på egen grundläggande oförmåga eller otur eller någon banal händelse vilken som helst tillintetgjorts innan de hunnit anpassa sig; de sackar efter, börjar inte lära sig tyska $\propto$ ch lyckas inte orientera sig i den infernaliska labyrinten av lagar och förbud förrän deras kroppar redan är stadda $\mathrm{i}$ upplösning och ingenting skulle kunna rädda dem från att gallras ut eller dö av utmattning ... [s 100-101].

Räddningens vägar är enligt Levi många och oförutsedda. Det första sättet är att bli "prominent", dvs en lägerfunktionär av något slag. Ett annat sätt är att helt på egen hand kämpa för att överleva:

Det gäller att gå emot strömmen, att varenda dag och varenda timme göra front mot slitet, hungern, kölden och den slöhet som blir följden, att hålla stånd mot fienderna och inte ha förbarmande med rivalerna, att skärpa intelligensen, öka tåligheten och stålsätta viljan ... [s 103].

I fortsättningen berättar Levi hur han blev kemist $i$ lägret. Det började med ett förhör inför doktor ingenjör Pannwitz och anställningen förverkligas senare till Levis egen överraskning. Detta var säkert en bidragande orsak till att han klarade sig. Ett remarkabelt avsnitt är det redan nämnda stället om hur Levi reciterar ur Dantes Divina Comoedia för en ung pojke, Jean, på grund av sin syssla kallad Pikkolo:

Betänk ert ursprung: ni blev inte födda att leva som de oskäliga djuren

men till att söka efter dygd och kunskap.

"Det är som jag själv hörde det för första gången: som en trumpetstöt, som Guds röst. För ett ögonblick glömmer jag vem jag är och var jag är" [s 129]. "Jag håller kvar Pikkolo, han måste lyssna nu, han måste begripa detta "come altrui piacque" ('så som de Högste velat'), innan det är för sent, i morgon kan någon av oss vara död..." [s 130-131].

Primo Levi berättar om hur man började få vetskap om de allierades landstigning i Normandie och Sovjets offensiv på östfronten. Dessa uppgifter hade väckt vissa kortvariga förhopp- ningar, men då befrielsen lät vänta på sig hade man redan hunnit försjunka den apati som sade att alla förändringar i lägret är till det sämre. Men från och med augusti 1944 började bombanfall âterkomma over Sydschlesien och de avbröt och satte snart stopp för byggnadsarbetena $i$ Buna. Som sådana var bombanfallen lika farliga för tyskarna som för fångarna. Men de hade änd̊̊ helt olika innebörd. Vid denna tid fick Levi en italiensk vän, en icke-judisk civil arbetare vid namn Lorenzo som varje dag kom med en brödbit och sina matrester, gav Levi en undertröja, skrev vykort till Italien för Levi och lät honom få svaret. "För allt detta begärde han aldrig och ville aldrig ta emot någon som helst ersättning, eftersom han var god och renhjärtad och inte ansåg att man gör välgärningar för att bli belönad" [s 136]. "Tack vare Lorenzo", skriver Levi, "glömde jag inte bort att jag själv var en människa" [s 139].

I lägret blir en motståndsman hängd: han ropar, när snöret dras runt halsen: "Kameraden ich bin der Letzte!" Levi kommenterar det med: "nu kan ryssama komma: det finns inte längre bland oss några starka män, den siste hänger ovanför våra huvuden, och för dem som var starka behövdes inte mer än några få rep" [s 170].

De tio sista dagarna $i$ lägret sker uppbrottet. Levi befinner sig i sjukstugan. Många andra patienter ger sig av med huvuddelen av lägret på den fruktansvärda marschen till Gleiwitz, $70 \mathrm{~km}$ bort. De var rädda för att bli kvar i tron att tyskarna skulle likvidera lägret, när de bröt upp. Men de flesta omkom under marschen. Levi stannar kvar. Folk dör också i sjukstugan i sina olika smittosamma sjukdomar. Man lever på potatis och rester av mat som blev kvar. En spöklik stämning breder ut sig över det nästan tomma lägret. Ryssarna anlände den 27 januari 1945. Det skulle dröja ända till oktober innan Levi kom hem till Turin.

Efterskriften från 1976 har många upplysande kommentarer och svar på frågor som ställts till författaren. Levi säger sig inte ha något hämndbegär genemot tyskarna: "Jag skulle likväl inte vilja att det faktum att jag avhåller mig från att fälla en uttrycklig dom uppfattades som en urskillningslös förlåtelse. Nej, jag har inte förlåtit någon av de skyldiga och jag är inte heller villig att förlåta någon av dem, varken nu eller $i$ framtiden, försåvitt vederbörande inte visat (i handling, inte $i$ ord och inte för sent) att han blivit medveten om vilka illgämingar och misstag fascismen i vårt land och utomlands begått 
och beslutat att fördöma dem, utrota grunden till dem i sitt $O c h$ andras medvetande. I sá fall är jag som icke-kristen benägen att följa det judiska och kristna budet om att förlåta min fiende; men en fiende som ångrar sig är inte längre en fiende" [s 203-204].

Han får frågan om varför han talar enbart om de tyska lägren och inte de ryska. Svaret är att han vill tala bara om det han av egen erfarenhet känner till. Men han tillfogar, att förintelsen i tyska lägren var nästan total (90-98\%), medan den i de ryska skall ha legat kring $30 \%$. Det berodde på att lägerfångenskapen $i$ de tyska inte kände något slut, medan den ry ska fångenskapen var om än lång i alla fall begränsad [s 217].

Författarens död. Primo Levi dog den 11 april 1987 - 68 år gammal. Han föll ned i trapphuset från tredje våningen $\mathrm{i}$ det hus han bodde. Man har allmänt antagit, att det var frågan om självmord. Hans vänner visste, att han under den gångna vintern lidit av depression och att han en vecka tidigare hade blivit oppererad. Ändå var det flera, bl.a. en mångårig väninna, Rita Levi Montalchini, som ansåg att det inte var möjligt att Primo Levi tagit sitt liv. Hon hänvisade till att han principiellt var emot självmord, också ett "etiskt självmord" p.g.a. erfarenheterna från lägren. Hon menar, att något sådant står $\mathrm{i}$ strid med Levis budskap också i hans sista bok: att människan kan rebellera mot lydnaden, vad den än gäller. Hon menar därför, att han helt enkelt greps av ett svaghetstillstånd och föll när han lutande sig mot räcket mot trapphuset.

Men Risa Sodi ${ }^{33}$ analyserar Levis sista bok (I sommersi $e$ i salvati. 1986) som innehåller några rader, som eventuellt kastar ett ljus över hans egen död. Han framhåller, att när fångama var i lägret, var det farligaste de kunde göra att tänka på det förflutna. De befriades största fara var att tänka på lägererfarenheterna. Han säger: "Jag tror att det var just detta att vända sig om och se tillbaka på 'de farliga vattnen' som gav upphov till de många självmorden efter, ibland starx efter, befrielsen" [Sodi 103]. Vi vet att Levi gång på gång gjort det här - han såg tillbaka, erinrade sig och berättade. Han hade ett enormt behov att berätta, säger han själv, liksom en katolik som går i bikt, eller en person som går i psykoanalys. Man gör sådant för att bli fri från det som trycker på ens sinne, men man lyckas inte alltid. Kanske fờ att så många ändå inte är intresserade eller för att upplevelserna är så overväldigande. ${ }^{34}$

\section{Exempel 2: Wiesel: La Ville de la Chance}

Elie Wiesel (f. 1928) fördes från sin hemstad Sighet i Transsylvanien till Auschwitz i maj 1944. Han befriades i Buchenwald ett år senare och fördes till ett uppsamlingsläger för föräldralösa barn i Normandie. Hans mor och yngsta syster fördes direkt till gaskammaren i Birkenau, hans far dog i Buchenwald, medan hans två ăldre systrar överlevde. Före La Ville de la Chance (1962) hade han publicerat två självbiografiska böcker och två romaner. ${ }^{35}$

Efter lägertiden var, skriver Wiesel, för honom "alla slags alternativ öppna: självmord, vansinne, dődande, politisk aktivitet, hat, vänskap, blasfemi, ateism, förnekelse, förkastande av människan, förtvivlan. I varje bok utforskar jag en aspekt: i Gryningen utforskar jag politisk aktivitet, i Le Jour självmordet, i La Ville de la Chance vansinnet, i Les Portes de la Forêt tro och vänskap, i Le Mendiant de Jérusalem historien, återvändandet. Alla berättelserna är en enda, frånsett att jag bygger upp dem $\mathrm{i}$ koncentriska cirklar. Men centrum är detsamma som i $\mathrm{La}$ Nuit." ${ }^{36}$ De två första fiktiva lösningarna eller svaren på det radikalt onda befanns vara inadekvata. I sin tredje roman utgiven 1962 under titeln La Ville de la Chance ${ }^{37}$ prövar Wiesel vansinnet som lösning. Det annonseras redan i mottot för boken hämtat från Dostojevskij: "Jag har en plan: att bli galen".

Handlingen sker inom ramen för ett besök som en ung överlevande, Michael, gör i sin ungerska hemstad. Staden heter Szerencseváros vilket betyder "lyckans stad". Det självbiografiska inslaget är tydligt, fastän Wiesel själv besökte sin hemstad Sighet först år 1964, två år efter det att boken utkommit. ${ }^{38}$ Besöket är fiktivt,

33 Sodi 1989.

34 Jfr L. Eitinger, On Being a Psychiatrist and a Survivor, i Rosenfeld, 194-197, som behandlar bl.a. Bettelheims, Frankls och Wiesels uppfattningar om lägren

35 Se Illman 1988, 87-90.

36 Cargas 1976, 86, anfört enligt McAfee Brown 1983, 51.

37 Jag använder av praktiska skäl att hänvisa till den norska översättningen Lykkens by utgiven redan 1964.

38 Se essän The Last Return i Wiesel 1982, 110-130. 
men Michaels bamdomsmiljö densamma som författarens. Detta drag förstärks ytterligare av att Michael träffar en ung mycket religiös jude som hör hemma i Marmaroszighet, dvs författarens Sighet.

På vilket sätt prövas vansinnet? Handlingen börjar i Paris, dăr den unge Michael lider nöd han svälter, han håller på att mista förståndet, när en ung judisk pojke som han träffat i lägren blir överkörd och dör på ett sjukhus. Genom en barndomsvän kommer han i kontakt med en spansk jude, Pedro, som hädanefter kommer att spela en roll i flera av Wiesels romaner. Denne Pedro kommer underfund med att Michael när på en längtan att besöka sin barndomsstad i Ungern. Eftersom han arbetar i en underjordisk flyktingorganisation lovar han att arrangera besöket. Själv för han Michael till gränsen, en annan tar emot honom och för honom till staden och de avtalar att träffas tre dygn senare. Michael vandrar omkring i sin barndoms stad, ser att den stora synagogan brännts ned, besöker sin fars gamla butik, känner inte igen någon människa - utom en, "åskådaren", och förstår att det egentligen är för hans skull som han återvänt. Här kan man säga, att ett viktigt sidotema förs in. När stadens judar evakuerades fördes de först till synagogan, där de fick vänta på sin tågtransport. De vistades inne i synagogan eller på dess gård. Grindarna var väl bevakade. På andra sidan gatan fanns ett hus och $i$ ett fönster syntes ett runt ansikte med stora blå, likgiltiga ögon, som betraktade judarna. Denne har en motsvarighet vid Wiesels avfärd från Sighet vilket han berättat i en essä. Robert McAfee Brown ${ }^{39}$ vill sätta in åskådarrollen som en av de möjligheter Wiesel prövar. inte offret, inte heller bödeln, men kanske den neutrale åskådaren? Men är detta verkligen ett alternativ i Wiesels mening? Det förefaller mig som denna åskådare från början behandlas med förakt. Själv beteckande Wiesel "galenskapen" som den "option" han prövade i den här boken. Här låter han Michael säga:

Efter kriget var det först och främst detta jag ville förstå. Inget annat. Hur kunde man förhålla sig likgiltig. Jag förstår bödlarna; offren likaså, fastän det är svårare. Men de andra, alla de andra, de som var varken för eller emot, de som fann sig väl tillrätta med att passivt vänta, de som sa till sig själva: "Ovädret drar förbi, allt kommer $i$ ordning igen", de som hävdade att de stod över stridens tumult, de som intog åskådarens hållning - de var en sluten vărld för mig, dem förstod jag absolut inte [Lykkens by 165].

Michael uppsöker åskådaren, som bor kvar i sitt gamla hus, stiger in utan att knacka på. Åskådaren känner honom givetvis inte, undrar om Michael är en polis och drar själv slutsatsen att han inte är det. Polisen är den ende han är rädd för. $\mathrm{Nu}$ utspinner sig ett samtal. Michael säger att han kommit för att förödmjuka den andre, påminner honom om maj 1944, när deportationerna inträffade. Frågar om han inte kände någon som helst medömkan över judama. $\mathrm{Nej}$, det gjorde hans fru, men inte han själv, inte det minsta. Han påpekar att judarna ju blivit förvarnade, de hade kunnat fly, eller göra uppror. Han säger till Michael: "Ni hatar mig, inte sant?" "Nej, sa jag. Jag hatar er inte... Jag föraktar er. Det är värre ..." [s 176]. Han måste därför förnedra åskådaren och han gör det genom att tömma de två vinglas som han satt fram $i$ ansiktet på honom. När Michael slutligen går kommer han bara ett kvarter, innan han blir upphunnen av en polisbil med åskådaren i framsätet. Nu måste väl Michael ändå hata honom. Men Michael ser honom nu som mera mänsklig, som offer, bödel och åskådare i en person. Brown anser väl med rätta att Wiesel är påverkad av Buber [McAfee Brown 73]. Buber ansåg, att den som hatar kommer närmare en relation till en annan än den som varken hatar eller älskar. För Wiesel är likgiltigheten den största synden av alla. Han anklagar både Gud och människor för likgiltighet. Man påminns om titeln till Nattens föregångare, Wiesels förstlingsverk Un die Velt hot geschvign, "Men världen teg". Och Gud - är han också en åskådare?

Michael blir nu förd till häktet och förhörd om sin avsikt med återvändandet. Detta är orsaken till att huvudpersonen $i$ ramberättelsen befinner sig häkte. Där tillämpas en mycket enkel form av tortyr. Fången måste stå upprätt framför en vägg - det kallas "att be" med anspelning på den judiska böneställningen - enda avbrottet kommer var åttonde timme då han eskorteras till toaletten. De flesta börjar tala redan efter ett dygn - förr eller senare bryter de samman fysiskt eller psykiskt. Tre dygn brukar räcka till. Michaels liv passerar i revy: han uppehåller sig spe- 
ciellt vid Moishe, en god văn till hans bamdoms familj. ${ }^{40}$ Moishe var galen i den profetiska meningen: "I dessa tider kan uppriktiga människor göra bara en sak: bli galna". Där finns också den urgamle grannen Varady, ett urspårat lärdomssnille som ger sig ut för att vara odödlig: han tar sitt liv när tyskama kommer till staden. Slutligen finns där läraren Kalman, som är galen, och två av hans elever Hersh-Leib och Menashe, som vardera blir det. Genom bön och askes vill de påskynda Messias ankomst. Den tredje eleven, Michael, räddas från samma öde inte av Messias utan av tyskamas ankomst. Detta är den enda av scenerna i boken som har en självbiografisk grundval: han själv var den tredje eleven [Brown 76].

Också Michael kollapsar under ett förhör med en vakt som uppträder mycket vănligt, vill vinna hans förtroende. När han vaknar upp befinner han sig $i$ en cell med tre andra făngar. juden Menachem från Marmaroszighet, som hela tiden ber till Gud och uppmanar Michael att göra detsamma, den tyste ynglingen som inte uppfattar något längre och den otålige som försöker ta livet av sina cellkamrater i tur och ordning för att han misstänker att de tagit ett brev som tillhör honom. Frestelsen för Michael att ge efter för vansinnet är nästan oemotståndlig - det skulle vara så lätt att dra sig undan verkligheten. Men Michael står emot och han kommer att rädda en av de andra fångarna från vansinne - den tysta ynglingen, som han med olika övningar kallar tillbaka till verkligheten.

Under handlingens förlopp sker som Brown [s 82] påpekar en förvandling av Michael: han ville vara ensam och drog sig undan de vänner och bekanta från det förflutna som dyker upp. Men mötet med Pedro drar honom ut ur ensamheten:

Det grydde till dag. Elden steg upp från jorden och satte himlen $i$ brand. Det gick plötsligt upp för Michael att han hade nått en vändpunkt: han genomlevde ett av de ögonblick då ödet iakttog honom. Han kănde hjärtat dunka i kroppen. Han stod vid en korsväg. Skulle han gå till höger eller till vänster? Oavsett hur han valde, skulle valet få följder för framtiden [Lykkens by 129]
- Du skrämmer mig, sa Pedro. Du vill avskaffa lidandet genom att driva det till sin spets, in i vansinnet. Săger du "Jag lider, alltså finns jag till", så blir du mănniskans fiende. Det som du bör säga är "Jag lider, alltså finns du till". Camus har på något ställe sagt, att vi bör skapa lycka för att protestera mot ett universum av olycka. Den är en pil som visar den väg vi bör gå: den för till din nästa och inte genom det absurda. Bland alla de ord Michael hade hört Pedro säga, var det dessa som senare kom honom till hjälp [s 134].

McAfee Brown [s 85-86] antar att det dessutom har en symbolisk betydelse att ynglingen heter Menachem, "Tröstaren", och att denne religiöse jude kommer från Marmaroszighet från vilket det inte har kommit någon som helst tröst under alla dessa mellaliggande år. Michael föraktar först Menachems tro, men börjar till slut gråta. Den som han hjälper är den tyste som han återför till ljuset: han skall inte bara ge en död kropp liv utan också rädda själen, ge ynglingen tillbaka hans förstånd. Eller med Pedros ord:

Det är precis det jag vill att du skall göra. Återskapa universum. Ge pojken förståndet tillbaka. Gör honom frisk. Han skall rädda dig [s 190] citat:

Resultatet kan summeras med ytterligare ett

Michael mötte daggryningen som en ny människa. Han hade fătt sin kraft tillbaka. Plötsligt kände han sig ansvarig för ett liv som sammanföll med människosläktets. Han skulle kämpa. Han skulle utifrån ingenting börja skapa världen på nytt. Abrahams och Adams Gud, jag ber dig var inte "emot" mig den här gången [s 191].

Detta är vad McAfee Brown har kallat vägen "From Silence to City" i Wiesels författarskap.

Målet var ännu inte nått utan vägen fortsatte i de följande romanerna. Frågan är dock om en författare som Wiesel någonsin skulle kunna säga att målet är nått eller att svaret som innehåller botemedelet för detta monstruösa är funnet. Knappast. I en artikel kallad "Why I Write"

40 Se essän "Moshe the Madman" i Wiesel 1982, 73-86. 
săger han bl.a. att han inte skriver för att bevara sin mentala hälsa. Tvärtom, författarskapet för honom till avgrundens brant. Han hade heller aldrig för avsikt att bli teolog eller filosof - utan vittne. Detta uppdrag är till sin natur livslångt.

Det är två ganska olika böcker som ovan presenterats. Levis memoarer är visserligen skrivna efter lägertiden, men kort efter. De är i hög grad dokumentära, detaljerade och faktainriktade. Men de kommenterar hela tiden det skedda. Den subjektiva sidan, uppevelsesidan är hela tiden invävd i beskrivningen. De har en ram som består av inledningsdikten och de avslutande svaren på frågor, som visar att författaren inte bara vill dokumentera utan också påverka de efterkrigstida tänkesätten genom att visa hur långt avhumaniseringen gått. Wiesel åter skriver från början till slut fiktivt, dock så att hans egna upplevelser i samband med deportationen, lägervistelsen och reflexioner efterǻt făr leverera material till romanen. Vad är en adekvat reaktion på det groteska som hänt? Michaels kamrat hade valt vansinnet, Michael blir det nästan själv innan han kan hjälpa den andre ut genom att lida med, genom dialogen. Detta intresse för andra som lider och bibehållandet av de egna värdena var viktiga förutsättningar för överlevandet $\mathrm{i}$ lägren, framhåller Leo Eitinger med Wiesel som exempel. ${ }^{42}$

Omöjligt är att säga vilkendera som har en starkare förankring i verkligheten, därför att det som sagt alltid rör sig om tolkning, redan i upplevelsen och sedan i minnet av det skedda. Den fiktiva áterskapelsen, som hos Wiesel, kan vara lika verklighetstrogen som någon dokumentation.

När man behandlar förintelsen och litteraturen om den, finns det flera sätt att försöka neutralisera den förtvivlan som konfrontationen med den lätt leder till. Man kan göra som förintelseteologerna (judiska och kristna) - man säger att förintelsen är den "död" som átföljs av en "uppståndelse", t.ex. grundandet av staten Israel. Eller man kan citera Albert Camus: "Att tala om förtvivlan är att besegra den". Eller man hänvisar till att förintelsen var kulminationen på nazisternas vansinne som nu ligger 45-50 år bakåt $\mathrm{i}$ tiden. Man kan tillfoga, att det tyska folket ju också fått sona nazisternas brott... Men kan någon uppståndelse bli en kompensation för dem som fick sätta livet till? Kan någon mental övning verkligen ta bort udden av förintelsen, göra den mindre hemsk? Kan någon rättvisa skipas över sådana brott? Jag anser att alla dessa frågor måste besvaras med nej! Sådana fơrluster kan aldrig kompenseras, men man kan sörja över dem och i bästa fall transformera något av dem $\mathrm{i}$ positiv riktning. Också detta är en viktig aspekt på förintelselitteraturen. ${ }^{43}$

Det håller på att uppstå en litteratur också om de överlevandes barn, dvs barn till sådana föräldrar som suttit $i$ koncentrationsläger. Det har visat sig, att dessa barn i regel har haft mycket speciella uppväxtmiljöer och ofta fâtt problem som visat sig vara sinsemellan överraskande likartade. Föräldrama har undanhållit dem något, de har ofta inga far- eller morföräldrar - har egentligen aldrig haft, därför att detta är ett kapitel som man inte berör. Man har beskyddat dem för alla tänkbara faror o.s.v. Jag hänvisar här i första hand till Helen Epsteins redan klassiska De överlevandes barn (1990). ${ }^{44}$ Även Wiesels roman Den femte sonen kan räknas hit. Erfarenheten av förintelsen begränsar sig sålunda inte till en generation.

\section{Kritik mot förintelselitteraturen}

Det finns kritik som riktar sig mot själva förintelselitteraturen och studiet av den. Mest känt är filosofen Theodor W. Adornos ${ }^{45}$ uttalande: "Att skriva poesi efter Auschwitz är barbariskt". Han fortsätter "det innebär att man försöker pressa ett estetiskt behag ur en konstnärlig framställning av naket kroppsligt lidande hos dem som har blivit nedslagna med gevärskolvar ... Genom den estetiska stiliseringen ... framställs den obeskrivliga prövningen som om den hade någon yttersta mening. Den förvandlar och avklär händelsen något av dess förskräcklighet och redan därigenom görs orätt mot offren". Kanske finns här också tanken att de estetiska kraven på skönlitteratur är oförenliga med något så hemskt och fult som Auschwitz. Det skulle vara att kontaminera litteraturen, kräva att den degenererar. $\AA$ andra

42 L. Eitinger i Rosenfeld/Greenberg 1978, 186-199.

43 Se Irwing Howe i Lang 1988, 198-199.

44 Det engelska originalet Children of the Holocaust. Conversations with Sons and Daughters of Survivors, utkom redan 1979. Jfr också Hass 1990.

45 Noten zur Literatur, vol 3, Frankfurt 1963, 125-127. Atergivningen enligt Irving Howe i Lang 1988, 179. 
sidan insåg Adorno också, att det inte finns något annat forum än litteraturen, där ett sådant lidande kan fă sin röst hörd. ${ }^{46}$ Jean-Paul Sartre hade för sin del direkt krävt, att vi måste skapa en litteratur som behandlar extrema situationer. ${ }^{47}$ I själva verket behövdes ju en sådan inte heller skapas: den judiska litteraturen har som sagt långa traditioner på detta område (jfr inledningen).

Man har senare kritiserat både den historiska och litterära sysselsättningen med förintelsen. Kritiken har gått ut på att "Holocaust Studies" speciellt i USA har fătt en så dominerande ställning inom judaistiken, att den enligt somliga hotar tränga undan andra judaistiska studier. Fơrintelsen har också blivit en symbol eller en "myt" som kräver en pendant, en "frälsning", som man också har funnit i sexdagarskriget 1967. Man har pekat på filosofer och teologer som Emil L. Fackenheim och Richard L. Rubenstein vilka skapat en judisk förintelse-teologi och man har ställt sig kritisk till denna. ${ }^{48}$

Man kan naturligtvis bemöta ovanstående med att säga, att det redan har skrivits så mycket om Auschwitz, att vi har att ta ställning till en forskning och en litterär verksamhet som faktiskt finns alldeles oberoende av vår inställning. ${ }^{49}$ Även om jag ger kritikema rätt $i$ att sysselsättningen med förintelsen inte borde få tränga undan det övriga studiet av judendomen, vill jag ändå framhålla att

1 - förintelselitteraturen redan genom de fakta den avslöjar väl hävdar sin plats bland det som förtjänar att bli läst. Det kan väl inte finnas för mycket dokumentation, för mycket data eller siffror om sådana händelser? Men det räcker ju inte heller med data, eftersom det alltid kommer att finnas skeptiker, som inte låter sig övertygas;

2 - förintelse-fenomenen måste studeras ingående, inte bara för deras implikationer för judendomen, utan också för kristendomen, som varit djupt och tragiskt involverad $i$ framväxten av förintelsen och som måste tillägna sig en ny attityd till judendomen; detta gäller väl för våra samhällen överhuvud, liberala, demokratiska, totalitära, som då inte förmådde stå emot det onda - skulle de kunna det idag?
3 - man kan se förintelsestudiet som ett medel att göra vår tids människor mera lyhörda för liknande företeelser som på olika håll igen börjar förekomma. Glömskan är som vi redan ser det sämsta av alla altemativa förhållningssătt;

4 - sist och slutligen är förintelselitteraturen en dokumentation av mänskligt lidande och ett minnesmärke över dem som inte fick några synliga gravar på jorden. Det är - som Wiesel sade viktigt att de döda får en posthum asyl undan förföljelser och tortyr som blev deras lott medan de levde.

Ytterligare en kritik går ut på att dessa verk genom sin form och sitt sătt att behandla fơrintelsen kommer att generalisera och inte lâta det speciella med förintelsen komma fram. Men detta är väl problem som anmäler sig vid varje framställning av en specifik händelse och förintelsen kan sägas vara en som utmanar vilken traditionell form som helst. Varje framställning, varje gång man skriver om förintelsen, är av nödvändighet samtidigt en form av distansering från förintelsen. Men det är det pris som måste betalas. Alternativet att tiga är ändå sämre.

Dessutom förefaller rädslan för att någon skulle studera förintelsen med för stor saklighet knappast vara befogad: ingen kan låta bli att rysa för de fakta som här kommer fram. Att underlåta att studera och skriva om förintelsen är enligt min mening inte försvarligt. Det öppnar bara vägen för glömska och allsköns förvanskningar, något som de s.k. revisionistema redan borde ha övertygat oss om.

Mot đenna bakgrund är det kanske lättast att förstå, varför dagböckerna och memoarlitteraturen har fått en så framträdande plats i litteraturen om förintelsen. ${ }^{50}$ De ger oss en unik möjlighet att leva oss in det som hände enskilda människor, sådana som vi själva. Alla var ju heller inte hjältar, starka eller sluga eller burna av en övertygelse. Att läsa om dessa vanliga offer gör oss mänskligare.

\footnotetext{
Ezrahi 1980,6-7.

What is Literature? New York 1949, 216. Jfr Ezrahi, 1980, 7.

48 Se Alter 1981, 48-54; Neusner 1981, 61-96; Illman 1982, 23-29.

49 Så Lang 1988, 2.

50 Så Howe i Lang 1988, 182.
} 


\section{BIBLIOGRAFI:: 51}

\section{Om förintelsen och litteraturen:}

Alexander, E. The Resonance of Dust. Essays on Holocaust Literature and Jewish Fate. Columbus 1979.

Alter, R. Deformations of the Holocaust, Commentary $2 \pi 1$, 1981, 48-54.

Auethahn, N.C./ D. Laub Holocaust Testimony. Holocaust and Genocide Studies,5, 1990, 447-462.

Berger, A.L. Crisis and Covenant: The Holocaust in American Jewish Fiction. State University of New York Press, New York 1985.

Cargas, H.J. Harry James Cargas in Conversation with Elie Wiesel, New York 1976.

Doneson, J.E. The Holocaust in American Film. Philadelphia, New York, Jerusalem 1987.

Eitinger, L. Mennesker blant Mennesker. En bok om antisemittisme og fremmedhat. Oslo 1985.

Eitinger, L. On Being a Psychiatrist and a Survivor, i Rosenfeld/Greenberg 1978, 194-197.

Eitinger, L. Elie Wiesel - Jgde - overlevende - menneske. Nordisk Judaistik 9, 2/1988, 99-107.

Epstein, H. Children of the Holocaust. Conversations with Sons and Daughters of Survivors. 1979.

Ezrahi, S.D. By Words Alone. The Holocaust in Literature. Chicago, London 1980.

Fine, E.S. Literature as Resistance: Survival in the Camps. Holocaust and Genocide Studies, 1/1986, 79-89.

Friedländer, $\mathrm{S}$. The Shoah between Memory and History. The Jerusalem Quarterly, 55, Winter 1990, 115-126.

Hass, A. In the Shadow of the Holocaust. The Second Generation. London 1990.

Howe, I. Primo Levi: An Appreciation. Introduction to P. Levi, If not Now, When? 1985 (se nedan under Romaner)

Host Heyderdahl, G. Glimt fra Elie Wiesels forfatterskap. Nordisk Judaistik 9, 2/1988, 92-98.

Illman, K.-J. Den teologiska holocaustlitteraturen. Nordisk Judaistik 4, 1/1982, 23-29.

Illman, K.-J. Litteratur om och av Elie Wiesel. Nordisk Judaistik 9,2/1988, 98 .

Illman, K.-J. Elie Wiesel - ett judiskt vittne. Teologisk tidskrift 1989, 475-480.

Lang, B. Act and Idea in the Nazi Genocide. Chicago, London 1990.

Lang, B.(ed.) Writing and the Holocaust. New York 1988.

Langer, L. Holocaust Testimonies. The Ruins of Memory. New Haven, London 1991.

Langer, L. Versions of Survival. The Holocaust and the Human Spirit. Albany 1982.

McAfee Brown, R. Elie Wiesel: Messenger to All Humanity. Notre Dame, London 1983.

Neusner, J. Stranger at Home. "The Holocaust", Zionism, and American Judaism. Chicago 1981.
Plank, K.A.The Survivors Return: Reflections on Memory and Place. Judaism 38 (1989), 263-277.

Rosenfeld, A.H. A Double Dying Reflections on the Holocaust Literature. Bloomington 1980.

Rosenfeld, A.H. / I. Greenberg (ed.) Confronting the Holocaust: the Impact of Elie Wiesel. Bloomington 1978.

Rousset, D. The Other Kingdom. New York 1947.

Roskies, D.G.Against the Apocalypse. Responses to Catastrophe in Modern Jewish Culture. Cambridge, Ma. 1984.

Rubenstein, R.L.

/ J.K. Roth Approaches to Auschwitz. The Legacy of the Holocaust. London 1987, 254-289.

Schindler, P. Hasidic Responses to the Holocaust in the Light of Hasidic Thought. Hoboken, NJ 1990.

Sodi, R. The Memory of Justice: Primo Levi and Auschwitz. Holocaust and Genocide Studies 1/1989, 89-105.

Wiesel, E. / P. de Saint-Cheron Evil and Exile. Notre Dame, London 1990.

Wiesel, E. Legends of Our Time. New York 1982 (1968).

Wiesel, E. Why I Write. I: Rosenfeld/Greenberg, 1978, $200-206$.

\section{Biografier, memoarer, dagböcker}

Bor, J. Requiem $i$ Theresienstadt. Stockholm 1968.

Donat, A. The Holocaust Kingdom. New York 1978 (1963).

Edvardson, C. Om Jag glömmer dig ... En invandrares dagbok. Stockholm 1976.

Hansson, K.M. / H. Kahan Ilden og lyset. Oslo 1988.

Kaplan, Ch.A. / A.I. Katsh Dödens dokument. Dagbok frän Warszawa. Stockholm 1965.

Lanzmann, C. Shoah. De överlevande berāttar. Förord av Simone de Beauvoir. Stockholm 1986.

Levi, P. Är detta en människa? Sthlm: Bonniers (Panache) 1988.

Fristen. Bonniers 1991. Orig. 1963.

Lewin, A. A Cup of Tears. A Diary of the Warsaw Ghetto. Ed. by A. Polonsky. London 1989 (1988).

Skjæraasen, M. Lege for livet. En bok om Lea Eitinger - medmennesket. Oslo 1988.

Sachnowitz, H. Det angär ocksả dig. Berättat för Amold Jacoby. Stockholm 1977 (1976).

Tory, A. Surviving the Holocaust. The Kovno Ghetto Diary. Ed. with an Introduction by Martin Gilbert. Cambridge, MA, London 1990.

Wiesel, E. Natten. Stockholm 1972.

Wiesel, E. One Generation After. New York 1982 (1970).

Wiesel, E. Legends of Our Time. New York 1968.

Wiesel, E. Lebensstationen, Kirche und Israel, 1987, 56-68.

Wiesenthal, S. Rättvisa - men inte hämnd. Memoarer. Stockholm 1989.

Willenberg, S. Surviving Treblinka. Ed. by Wladyslaw T. Bantoszewski. London 1989 (1986).

51 Utöver de arbeten som jag anfört i denna uppsats har jag hăr tagit med några för mig tillgängliga verk med en viss tonvikt på nordiska. Det behöver knappast påpekas att detta urval är begränsat. De anförda verken skall hur som helst uppfattas som exempel. För några skönlitterära verk anförs jämte originalen även översättningar som då markeras med *. 


\section{Antologier av förintelselitteratur}

Friedlander, A.H.(ed.) Out of the Whirlwind. A Reader of Holocaust Literature. New York 1976 (1968).

Glatstein, J.et al.(ed.) Anthology of Holocaust Literature. New York 1982 (1968).

Ramras-Rauch, G.

IJ. Michman-Melkman Facing the Holocaust. Selected Israeli Fiction. Philadelphia, New York, Jerusalem 1985.

Roskies, D.G. (ed.) The Literature of Destruction. Jewish Responses to Catastrophe. Philadelphia 1988. $652 \mathrm{~s}$.

\section{Romaner}

Edvard'son, C. Bränt barn söker sig till elden. Stockholm 1984. Edvardson, C. Viska det till vinden. Stockholm 1988.

Green, G. Holocaust. New York, London 1978.

Levi, P. If Not Now, When? Introduction by Irwing Howe. New York 1985.

Levi, P. Om inte nu, sḋ när? Bonniers (Panache) 1986.

Levi, P. Il sistema periodico. Torino 1975.

Levi, P.I sommersi e $i$ salvati. Torino 1986 * The Drowned and the Saved. New York 1988

Lundholm, A. Helvetesporten. Stockholm 1989.

Schwarz-Bart, A. Den siste av de rättfärdige. Helsingfors 1960.

Wiesel, E. L'Aube Paris 1960. * Gryningen. Stockholm 1973.

Wiesel, E. Le Jour. Paris 1961. * Dagen. Stockholm 1974.

Wiesel, E. La Ville de la Chance. Paris 1962. * Lykkens by. Oslo 1987 (1964).

Wiesel, E. Le Mendiant de Jerusalem. Paris 1968. * Tiggaren i Jerusalem. Stockholm 1971.

Wiesel, E. Den femte sonen. Stockholm 1985.
Summary: This paper is an introduction to and commentary on what is often referred to as the "holocaust literature". The author favors terms such as shoah or churban, which mean "catastrophe", "destruction" (Swedish: "förintelse") over the more widespread, "holocaust". The latter is a sacrificial term from the Bible meaning "burnt offering". This has misleading connotations: the destruction of European Jews cannot be considered a sacrifice in any ordinary sense. The paper discusses the various genres of "holocaust" literature and their relation to history. The author arrives at the conclusion that fictional literature need not necessarily have a weaker relation nor give a more faulty representation of what happened than documentary literature, such as diaries and memoirs. He gives one example of each, Primo Levi's Is this a Man? and Elie Wiesel's The Town Beyond the Wall. Finally various criticisms of "holocaust" literature and the preoccupation with it are discussed. The author finds no grounds for avoiding the study of this literature, to the contrary he argues that it is in fact necessary for later generations to know about and reflect on this dark chapter in human history. It is only deemed harmful if it then occupies the entire curriculum of Jewish Studies at an academic institution. 